\title{
The coupled thermal-hydraulic-mechanical behaviour of a large-scale in situ heating experiment
}

\author{
H. R. THOMAS*, P. J. CLEALL* ${ }^{*}$ D. DiXON† and H. P. MITCHELL*
}

\begin{abstract}
The thermo-hydraulic-mechanical behaviour of a large in situ heating test, the Buffer/Container Experiment (BCE), carried out at Atomic Energy of Canada's underground research laboratory, is considered. The work can be seen as an extension of the authors' previous research, investigating the behaviour of a large-scale test, the socalled 'isothermal test', to now include heating effects. Suggestions related to the micro-macro behaviour of bentonitic buffer materials subjected to resaturation in confined non-isothermal conditions are explored. Simulation of pre-heating phases of the experiment demonstrates the ability of the model to describe the hydraulic regime in the host rock and isothermal infiltration into the buffer. Consideration of the heating phase confirms that the temperature field is well understood, with a good correlation between the numerical and experimental results. In the moisture field it is found that the interaction between the emplaced buffer and host rock is of considerable importance. It is found that inclusion of micromacro interaction effects, by way of consideration of the impact of swelling and micro-macro interactions on the hydraulic conductivity of the material, yielded significantly improved correlations between observed and calculated results in the moisture field. The results of the numerical simulations suggest that the interaction between the emplaced buffer and host rock is strongly influenced by the micro-macro behaviour of the bentonitic buffer material. It is concluded that the consideration of the impact of micro-macro interactions on moisture flow in bentonitic buffers is of considerable importance, and may be of some significance in considering the total resaturation time as part of the performance assessment of a nuclear waste disposal repository.
\end{abstract}

KEYWORDS: expansive soils; full-scale tests; numerical modelling; partial saturation; radioactive waste disposal; temperature effects
La présente communication se penche sur le comportement thermo - hydromécanique d'un test de chauffage in situ de grande envergure, le Buffer/Container Experiment (BCE), effectué par le laboratoire de recherche sur le sous-sol de l'Atomic Energy of Canada (AECL). Ces travaux peuvent être considérés comme une extension de la recherche précédente de l'auteur, qui examinait le comportement d'un test à grande échelle, appelé le Test Isotherme, qui comprend maintenant les effets thermiques. On se penche également sur des suggestions relatives au comportement micro-macro de matériaux tampon bentonitiques soumis à une resaturation dans des conditions non isothermes captives. La simulation de phases de préchauffage de l'expérience démontre la capacité du modèle pour décrire le régime hydraulique dans la roche hôte, et l'infiltration isotherme dans la couche tampon. L'examen de la phase de chauffage confirme que l'on a bien compris le champ de température, ainsi que l'existence d'une bonne corrélation entre les résultats numériques et expérimentaux. Sur le plan de la rétention au champ, on a relevé que l'interaction entre le tampon mis en place et la roche hôte revêt une importance considérable. On a relevé que l'inclusion d'effets d'interaction micro-macro, par le biais de l'examen de l'impact de l'expansion et des interactions micro-macro sur la conductivité hydraulique de la matière, permet d'obtenir des corrélations sensiblement meilleures entre résultats observés et calculés sur la capacité de rétention au champ. Les résultats des simulations numériques semble indiquer que le comportement micro-macro du tampon bentonitique influe fortement sur l'interaction entre le tampon mis en place et la roche hôte. On en conclut que l'examen de l'impact des interactions micro-macro sur la teneur en humidité dans les tampons bentonitiques revêt une importance considérable, et pourrait même présenter une certaine importance pour l'examen du temps intégral de resaturation dans le cadre de l'examen du rendement d'un dépôt de déchets nucléaires à éliminer.

\section{INTRODUCTION}

The use of deep geological repositories for the disposal of high-level nuclear waste has received considerable interest over the past two decades. Several national organisations responsible for the safe disposal of such waste have developed significant research programmes to investigate various generic and site-specific issues related to the design and realisation of such repositories (AECL, 1994; European Commission, 2007; SKB, 2007). These programmes have

Manuscript received 1 May 2008; revised manuscript accepted 2 February 2009.

Discussion on this paper closes on 1 October 2009, for further details see p. ii.

* Geoenvironmental Research Centre, Cardiff School of Engineering, Cardiff University, UK.

$\uparrow$ Atomic Energy of Canada Ltd, Pinawa, Manitoba, Canada. resulted in large-scale in situ experiments being undertaken to study aspects of the full-scale behaviour of the proposed repositories (AECL, 1994; Dixon et al., 2002; Andersson et al., 2005; Huertas et al., 2005; Cleall et al., 2006; European Commission, 2007; SKB, 2007). Such experiments, while primarily designed to provide insight into the processes occurring, also offer the potential to explore the development and assessment of numerical models.

One such full-scale experiment, Atomic Energy of Canada Limited's (AECL) Buffer/Container Experiment (BCE), was conducted at AECL's underground research laboratory in Lac $\mathrm{du}$ Bonnet, Canada. The experiment involved placing a cylindrical heater into a vertical borehole, which was backfilled with a series of engineered clay-based buffer materials. The heater was introduced to represent the thermal load generated by a high-level nuclear waste package. The granite rock around the experiment could be considered to be 
unfractured and nearly saturated (Graham et al., 1997; Chandler, 2000). The experiment was conducted in conjunction with an isothermal buffer-rock-concrete plug interaction test (the so-called 'isothermal test'), which has been reported and studied elsewhere (Chandler, 2000; Dixon et al., 2002; Thomas et al., 2003). The key difference between the two tests is simply the inclusion of thermal loading in the BCE.

The work presented in this paper can be seen as an extension of the authors' previous research on the isothermal test (Thomas et al., 2003) to now include heating effects. Also, suggestions made in Thomas et al. (2003) related to the micro-macro behaviour of bentonitic buffer materials subjected to resaturation in confined non-isothermal conditions are explored further here.

Although details of the experimental configuration and the results obtained are presented in detail elsewhere (Graham et al., 1997), for completeness a summary of the set-up and results is given in the first sections of the paper. Application of an established coupled thermo-hydraulic-mechanical model (Thomas \& He, 1997, 1998) to simulate the experiment is then detailed. A series of numerical simulations of the various stages of the experiment are presented.

\section{EXPERIMENTAL SET-UP AND RESULTS}

The BCE was designed to simulate just one of the many boreholes that would be used to contain the used fuel disposal containers proposed in the AECL in-floor conceptual design put forward in the Environmental Impact Statement of 1994 (AECL, 1994). The experimental set-up is shown in Fig. 1. In this experiment a heater, representing a used fuel disposal container, was installed in a sand/bentonite buffer in a borehole $1.24 \mathrm{~m}$ in diameter and $5 \mathrm{~m}$ deep, in the floor of Room 213 excavated at the $240 \mathrm{~m}$ level in AECL's underground research laboratory. A thin layer of sand surrounded the heater, so as to provide thermal continuity between the heater and the surrounding buffer. The heater, buffer, backfill and host rock were extensively instrumented in order to provide a set of data measurements that could then be compared against a numerical analysis. The instruments were monitored prior to buffer emplacement, during the 896-day heating period, and, where possible, during decommissioning. The extent of the instrumentation in the buffer and the rock is illustrated in Figs 2 and 3 respectively, and is discussed in detail in Dixon et al. (2000).

The BCE can be divided into six discrete phases, as listed below.

(a) Phase A (280 days): drilling the emplacement borehole and monitoring.

(b) Phase B (30 days): installation of the buffer, backfill heater, and instrumentation.

(c) Phase C (170 days): a 'dwell' period during which temperatures, total pressures and water pressures were given time to stabilise.

(d) Phase D (896 days): the heating period, with power applied to the heater for a total of 896 days of continuous operation.

(e) Phase E (9 days): the decommissioning phase, in which the buffer and instrumentation were removed from the emplacement borehole.

( $f$ ) Phase F (230 days): a 'follow-up' period after the experiment, during which water pressures and temperatures continued to be read in the host rock, and the water seepage from the rock into the open borehole was monitored.

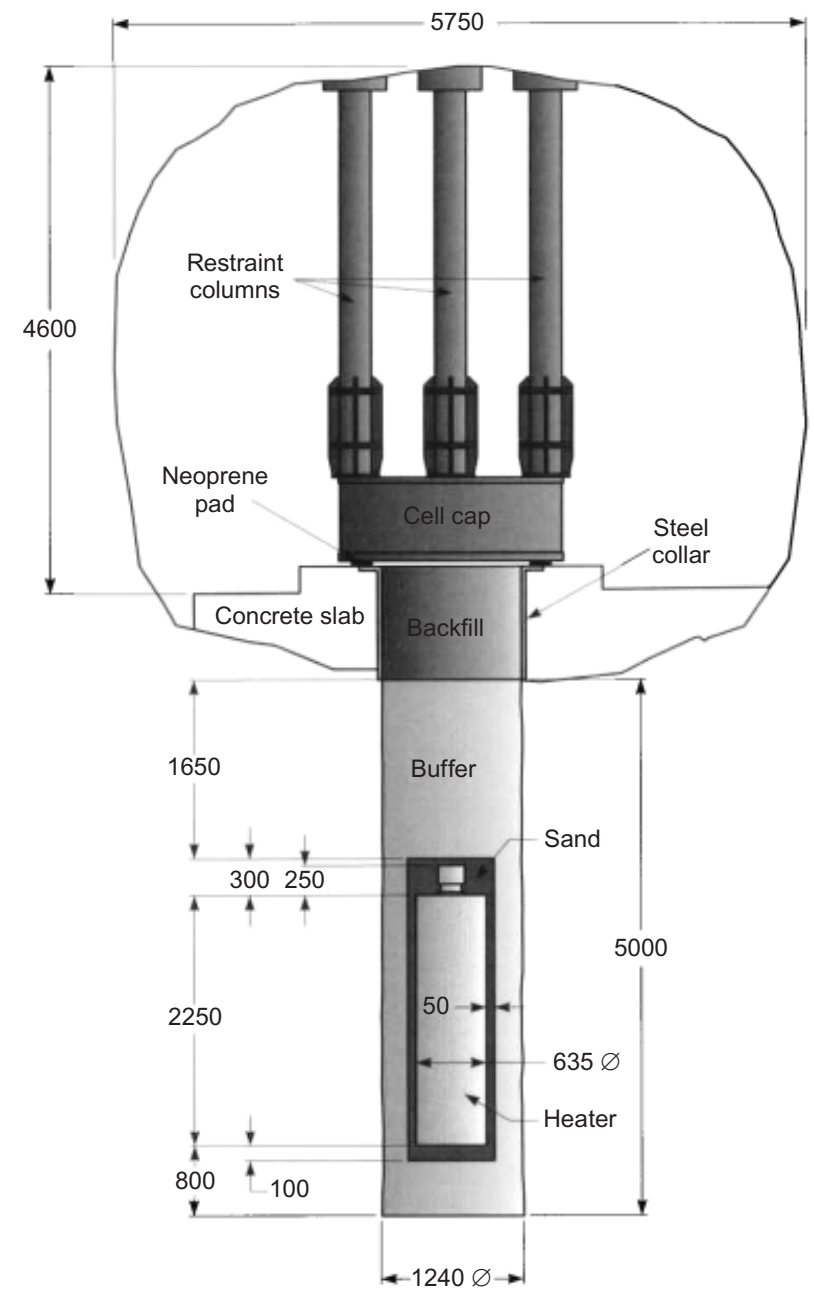

Fig. 1. Construction layout and dimensions of AECL's Buffer/ Container Experiment (after Graham et al., 1997). All dimensions are in $\mathbf{m m}$

\section{Temperature field}

Prior to construction, the granite rock had a temperature of approximately $11^{\circ} \mathrm{C}$. However, the temperature distribution was affected by construction of the tunnels and caverns. The air temperature within the tunnels varied from a low of about $12^{\circ} \mathrm{C}$ to a high of about $18^{\circ} \mathrm{C}$, with an average of $15^{\circ} \mathrm{C}$, prior to the heating phase of the experiment. Therefore there was a slight temperature gradient from the experiment room into the rock.

At the start of phase D, when the heater was activated, air heaters were installed in Room 213 of the underground experiment to maintain air temperatures at $15^{\circ} \mathrm{C}$. Initially the heater in the borehole was activated with a constant power of $1000 \mathrm{~W}$. After 25 days the heater power was increased to $1200 \mathrm{~W}$ so as to reach the target heater skin temperature of $85^{\circ} \mathrm{C}$. Rapid heating took place within the experiment, and only small changes in temperature occurred after 250 days of operation. A high level of axial symmetry was observed within the temperature measurements, reflecting the high level of axial symmetry in the experiment's geometry and the transverse isotropy of the thermal properties of the materials.

Figure 4 shows the experimental temperature results for a cross-section at the mid-height of the heater. There is a steep temperature gradient across the sand annulus, and across the buffer; the temperatures fall less steeply in the granite rock. The influence of variations of thermal conductivity due to the material type is clear. Fig. 5 shows the transient tem- 


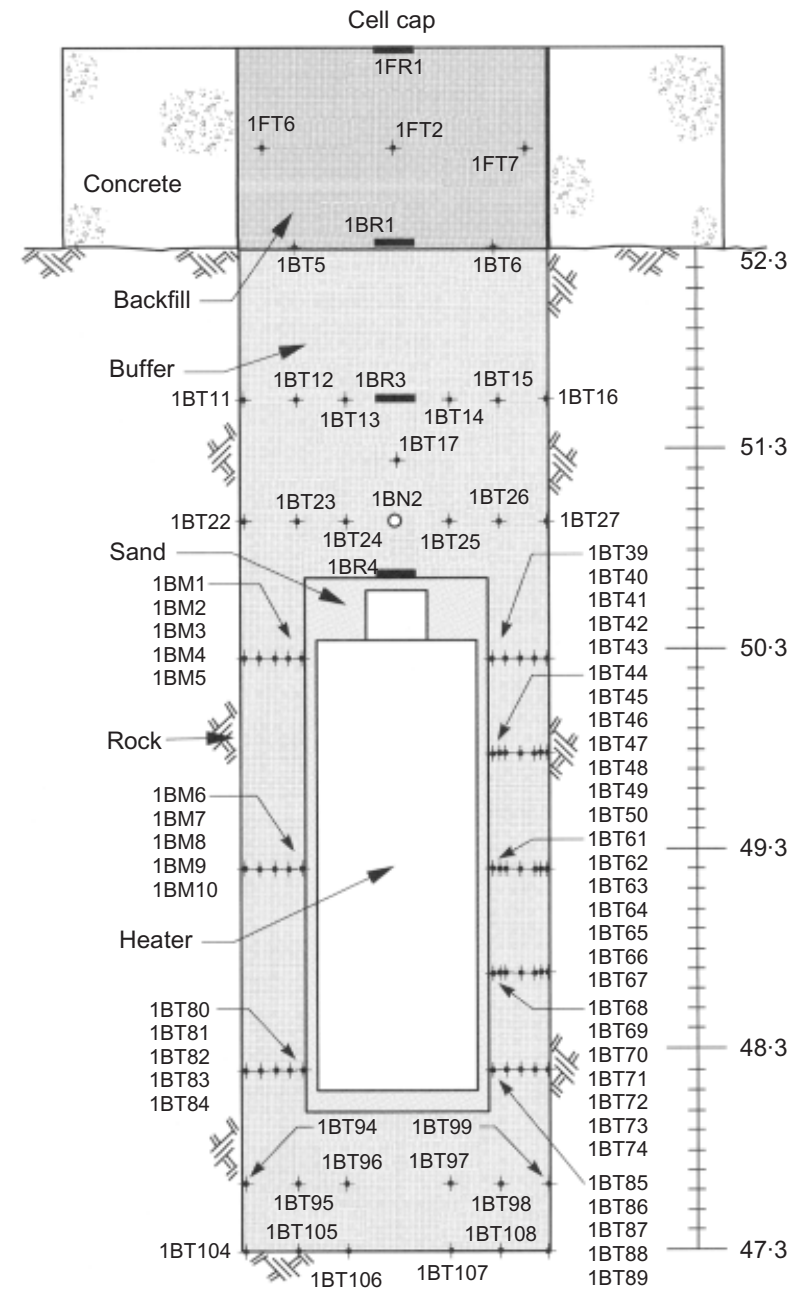

Fig. 2. Section through buffer showing thermocouples (BT, FT), thermistors (BM), earth pressure cells (BR, FR) and thermal needles (BN) (after Graham et al., 1997) perature profiles along the central axis of symmetry of the experiment. The maximum temperature occurs at the skin of the heater. The temperature gradient is steep across the sand annulus above and below the heater, becoming shallower across the buffer.

\section{Moisture field in the granite rock}

Prior to construction of the underground facility, the regional hydrostatic water pressure for the $240 \mathrm{~m}$ level was $2 \cdot 1 \mathrm{MPa}$. Following construction, water pressures at a few tens of metres away from the experiment were approaching $2 \cdot 1 \mathrm{MPa}$, and for a few metres of rock close to the excavation the drawdown of water pressures was steep. For a domain of $15 \mathrm{~m}$ radius it has been estimated that the farfield pore water pressure could be taken as $1.6 \mathrm{MPa}$ (Chandler et al., 1992).

The pore water pressure distribution in the rock was further affected by the drilling of the borehole, and placement of the unsaturated buffer. This was measured using hydraulic packers, some locations of which are shown in Fig. 3, and piezometers installed in the rock. The hydraulic packers had a series of inflatable packer strings that enabled the measurement of pore water pressure within the granite (Graham et al., 1997). The results measured by the hydraulic packers at the end of the 'dwell' period are shown in Fig. 6. Generally, the hydraulic packers performed well, and reliable readings were taken. However, the top cells in packer hole HG7 (3.5 m from the centre of the borehole) gave an unusual response. Also, the lowest cell in packer hole HG8 $(2.5 \mathrm{~m}$ from the centre of the borehole) produced readings that were much higher than expected.

The piezometers were installed closer to the borehole than the hydraulic packers. Both hydraulic piezometers $(\mathrm{RH})$, where a water-saturated chamber inside a high entry filter is used, and pneumatic piezometers (RP), which consist of a small chamber surrounded by a rigid walled material with permeable regions, were used: full details are reported in

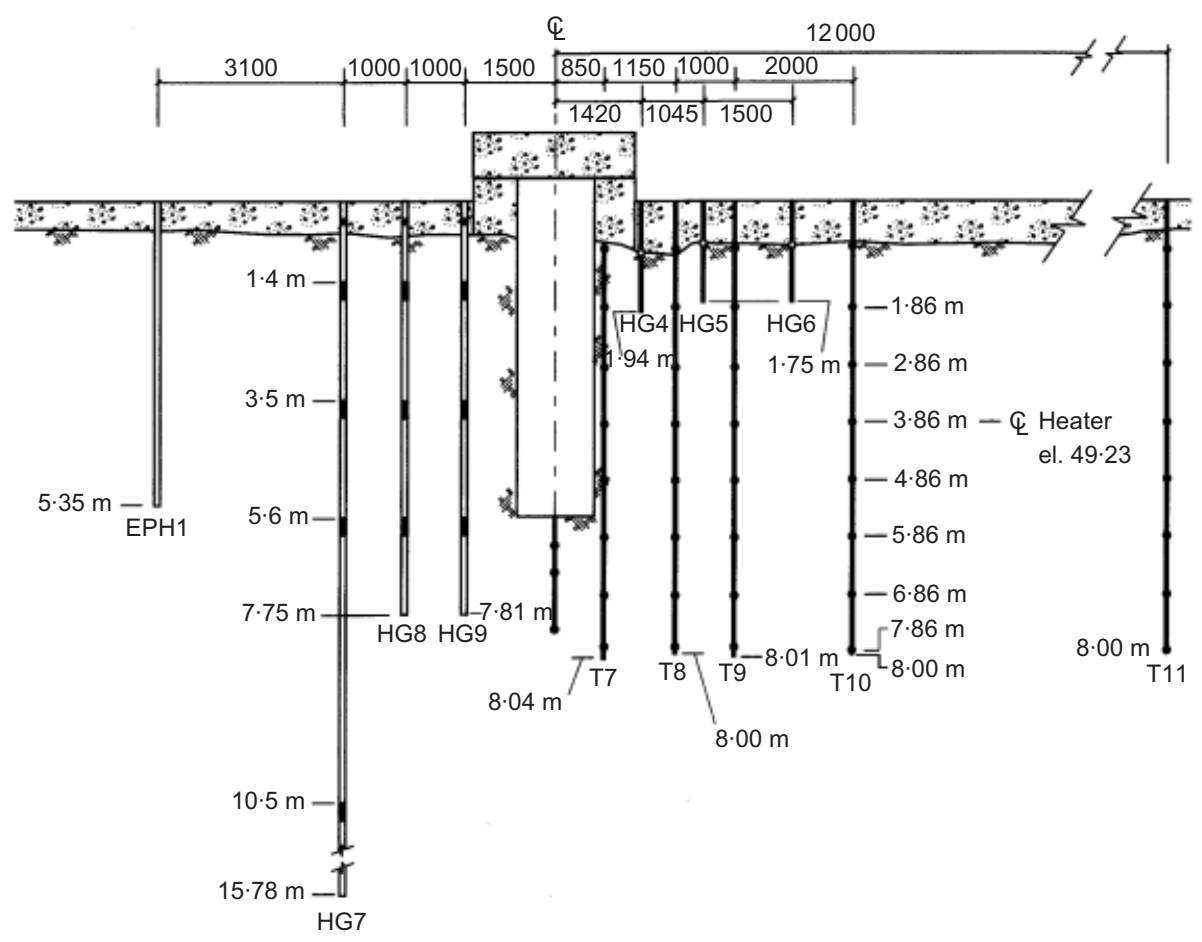

Fig. 3. Longitudinal section of Room 213, showing packer (HG) and thermistor (T) instrumentation in the rock (after Graham et al., 1997) 


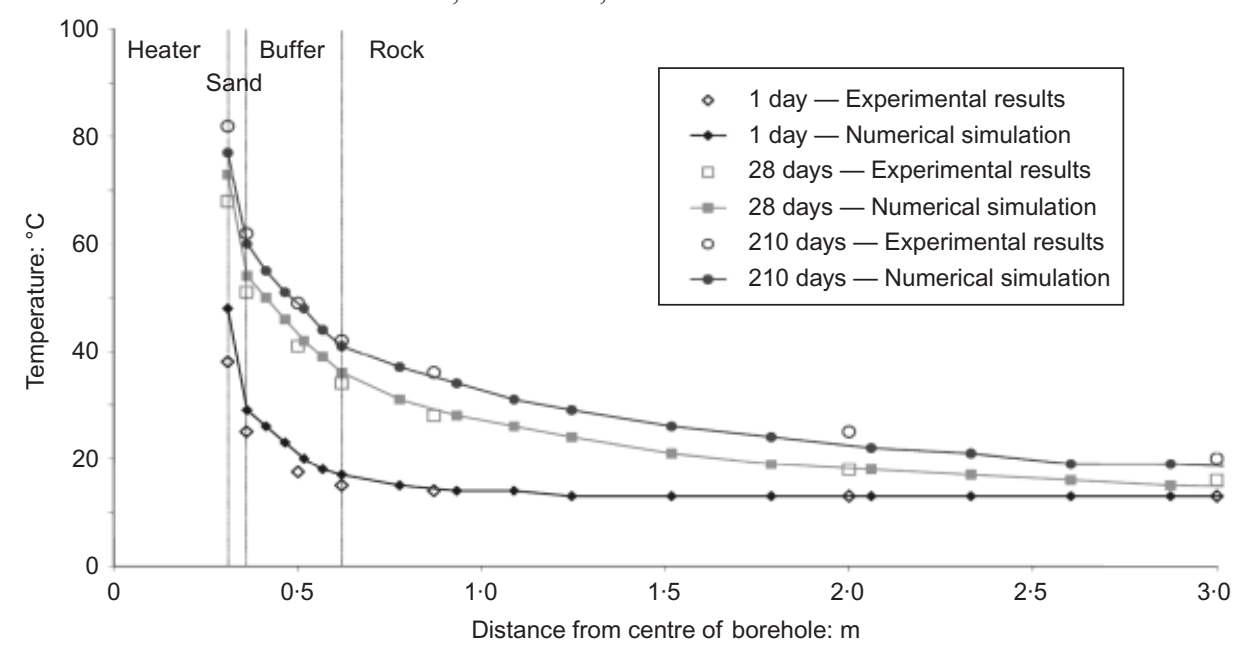

Fig. 4. Transient temperature profiles along mid height of heater

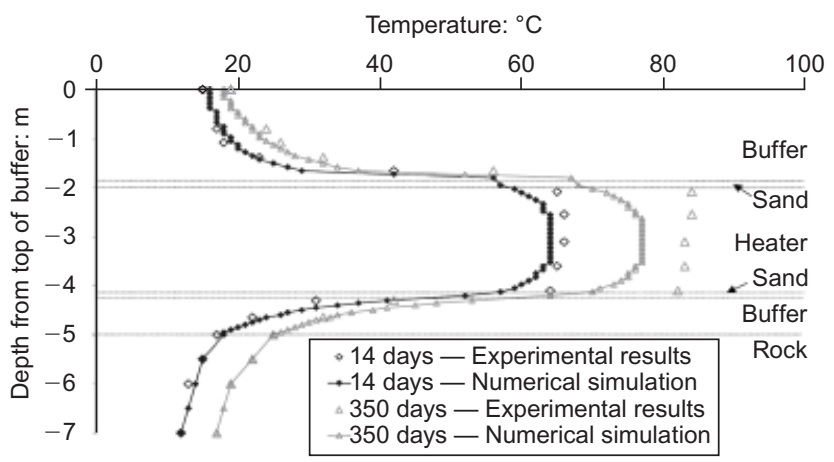

Fig. 5. Transient vertical temperature profiles through emplacement borehole centre

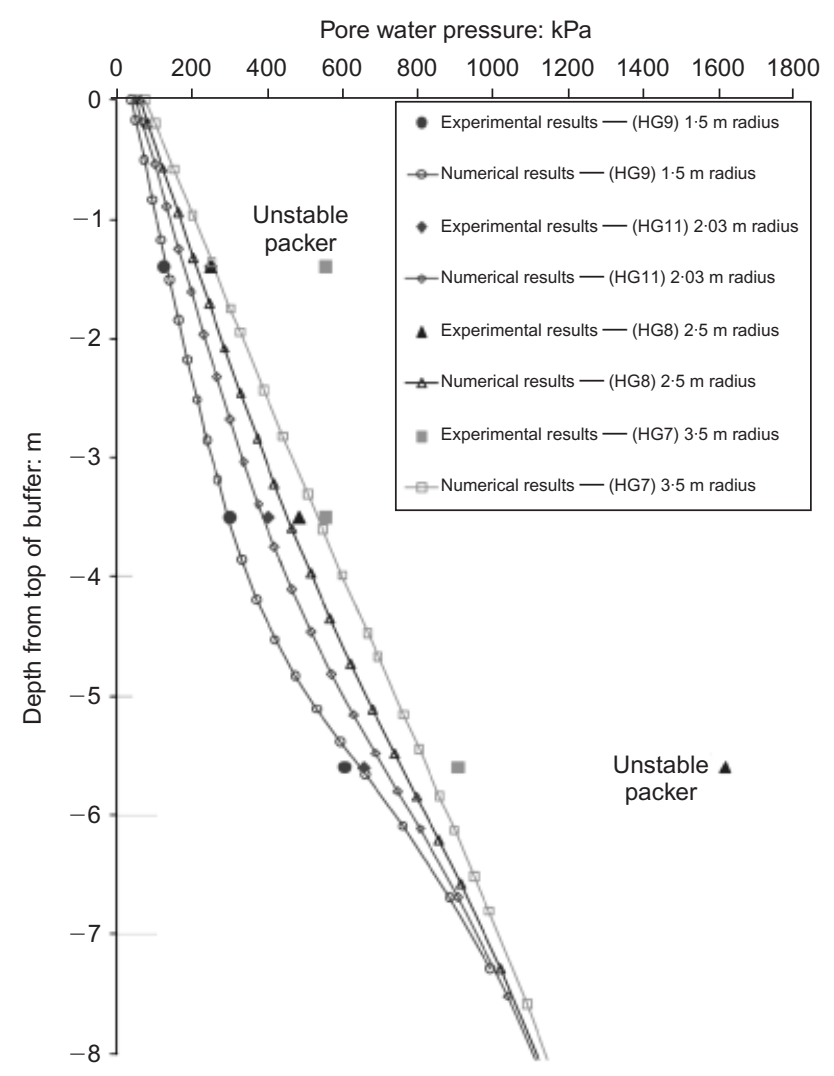

Fig. 6. Pore water pressures in packer boreholes at end of phase $C$
Dixon et al. (2000). The positions and response of the piezometers are listed in Table 1, which demonstrates that the piezometers were registering negative pore pressures in the rock for a distance of approximately $2 \mathrm{~m}$ from the centre of the borehole following placement of the unsaturated buffer. The actual values read by the piezometers are not given, as they cavitated when the suction in the rock approached $100 \mathrm{kPa}$; higher suctions could not be measured.

Following activation of the heater, the hydraulic packers and piezometers reached maximum pore water pressure values within approximately 150 days of operation. The piezometers registered negative pore water pressures following the dwell period. It was seen that the piezometric hydraulic pressures recharged during the heating period, and positive pore water pressures were observed in the majority of the piezometers after 100 days of heating. The hydraulic piezometers were located in a small region of leucocratic granite that had a larger porosity than the fine-grained granite in which the hydraulic packers were located. It was observed that the pore water pressures measured using the piezometers were lower than those measured using the hydraulic packers when comparing measurements at the same depth and radius within the experiment. The presence of the leucocratic granite could explain the variation between the pore water pressure results. However, the amount of leucocratic granite was small surrounding the experiment, so it would not be expected to influence the overall water balance distribution within the BCE.

The patterns of monitoring pore water pressure using various instruments may be followed in the contour plots of Fig. 7 and the cross-sections of Fig. 8. Where the packer

Table 1. Location of the piezometers

\begin{tabular}{l|c|c|c}
\hline Symbol & $\begin{array}{c}\text { Radius from } \\
\text { centre of } \\
\text { borehole: } \mathrm{m}\end{array}$ & $\begin{array}{c}\text { Elevation relative } \\
\text { to centre of } \\
\text { heater: } \mathrm{m}\end{array}$ & $\begin{array}{c}\text { Registering } \\
\text { negative pore } \\
\text { water pressure }\end{array}$ \\
\hline 1RH1 & 0.834 & +1.577 & Yes \\
1RH2 & 0.865 & $+0 \cdot 014$ & Yes \\
1RH3 & $0 \cdot 87$ & -0.92 & Yes \\
1RH4 & 0.87 & $-1 \cdot 82$ & Yes \\
1RP2M & 1.06 & $+0 \cdot 1$ & Yes \\
1RP3M & 1.35 & $+0 \cdot 1$ & Yes \\
1RP4M & 1.71 & +0.02 & Yes \\
1RP5M & 2.03 & +0.03 & Yes \\
1RP6M & 2.42 & +0.04 & No \\
1RP7M & 2.81 & +0.05 & No \\
\hline
\end{tabular}




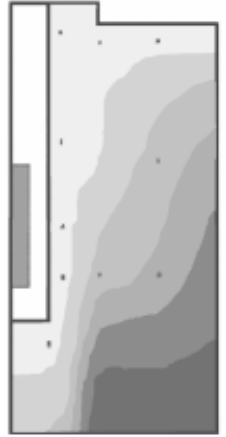

Day 30

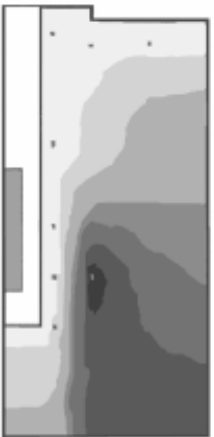

Day 150

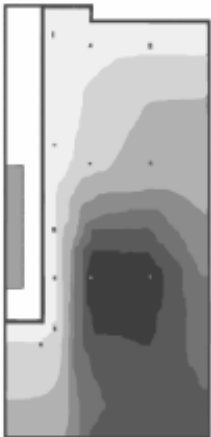

Day 400

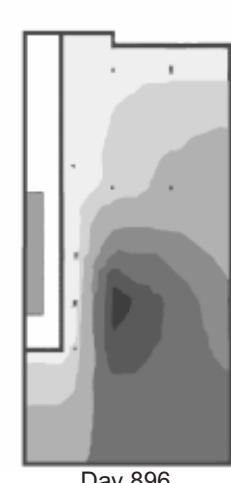

Day 896

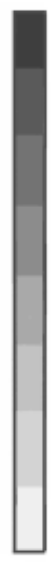

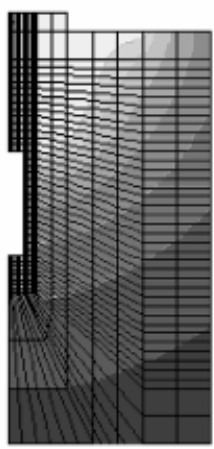

Day 150

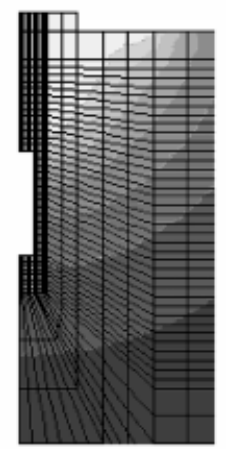

Day 400

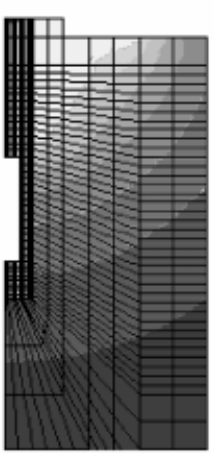

Day 896

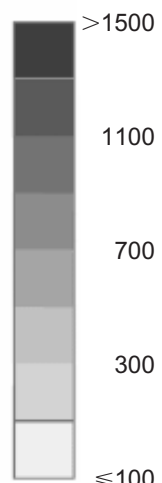

Pore water pressure: $\mathrm{kPa}$

Numerical simulation

Fig. 7. Transient pore water pressures for rock adjacent to borehole $(4 \mathrm{~m} \times 8 \mathrm{~m}$ domain)

label is marked with an asterisk, this indicates that the authors suspect that the packer was not registering true values, owing to large variations in the transient readings, but this could not be physically confirmed. The experimental contour plots in Fig. 7 show an isolated region of high pore water pressure. It is thought that this was due to instrument failure in two of the hydraulic packers. If the results measured using these packers are neglected, the contour plots would have a smoother profile, demonstrating a gradual increase in pore water pressure with depth below the cavern. Graham et al. (1997) thought that the early pressure peaks may have been due to thermal expansion in the pore water of the rock. However, it is thought unlikely that thermal expansion was the cause of such an isolated increase in the pore water pressure; furthermore, the times of the peak increase in pore water pressure do not coincide with the times of the peak temperatures.

\section{Water content and suction measurements in the buffer}

During the 'dwell' period and the heating period, thermal needles were used to measure the water content close to the heater where drying was expected to take place, whereas psychrometers were used in the regions that were expected to become wetter. Thermal needles measure the thermal conductivity of the soil, by way of measurement of temperature variations after a constant-power heating pulse, which is then compared with a previously determined relationship of thermal conductivity against moisture content (in this case the relationship defined below in equations $(5)-(7)$ ) to determine the in situ moisture content. Calibration tests indicated a good correlation between thermal conductivity and moisture content in the range $5-16 \%$ (Dixon et al., 2000). Thermocouple psychrometers were used, and calibration tests indicated that the experimental values of water content measured by the psychrometers were accurate only to within $\pm 6 \%$ of the indicated value (Wan et al., 1995a).

Figure 9 shows the measured transient pore water pressures for the buffer, interpreted by Graham et al. (1997). During the heating period, a region of drying was recorded close to the heater, and wetting was observed at the boundary between the buffer and the rock. The wetting at the buffer boundary is probably the result of a combination of moisture migrating from the heater to the outer edge and moisture being absorbed from the rock, as the pore water pressures in the rock recharge to positive values. During the decommissioning phase it was discovered that several of the thermal needles had corroded, and Graham et al. (1997) suggested that later readings from them should be interpreted as yielding qualitative rather than quantitative information.

End-of-test measured gravimetric water contents are compared with the thermal needle and psychrometer data in Fig. 10. Considering the large number and the direct nature of the end-of-test measurements, these are considered more reliable. The decommissioning data indicate more regular drying contours surrounding the heater; however, the general trends are similar. Similar trends of drying behaviour have been observed in other large-scale in situ tests (Villar et al., 2005).

\section{Total pressures in buffer and backfill}

Total pressure cells were installed in the buffer and the backfill to measure vertical and horizontal pressures. The 


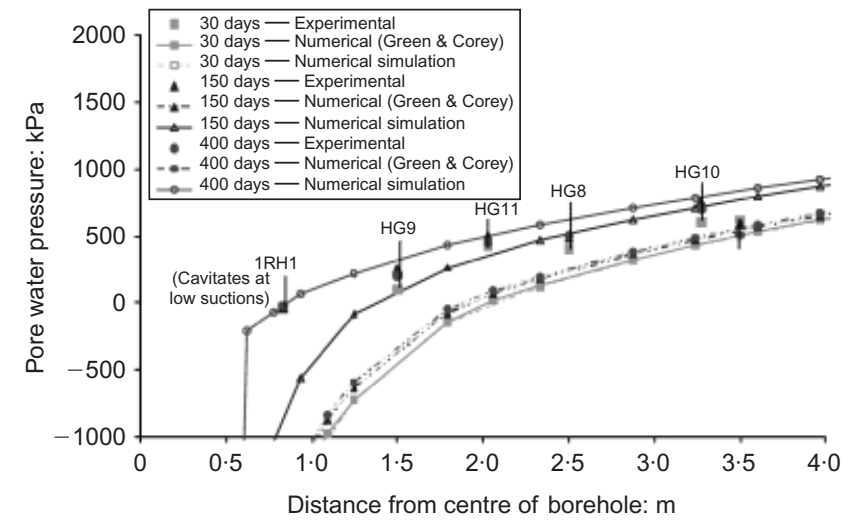

(a)

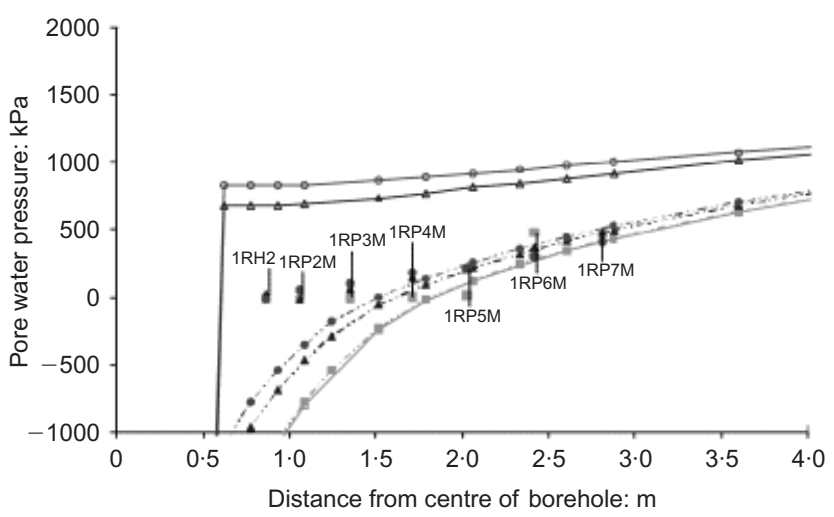

(b)

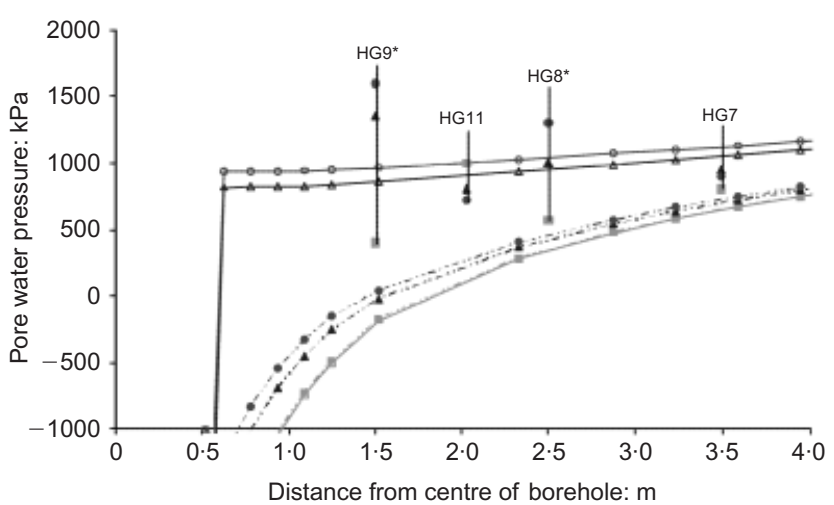

(c)

Fig. 8. Pore water pressure profiles at varying depths in the granite rock (HG, hydraulic packer; $\mathrm{RH}$ or $\mathrm{RP}$, piezometer): (a) depth $1.4 \mathrm{~m}$; (b) depth $3.0 \mathrm{~m}$; (c) depth $3.5 \mathrm{~m}$

locations of some of these cells are shown in Fig. 2, where the labels BR and FR refer to the pressure cells. Fig. 11 shows the distribution of pressure in the buffer and the backfill during the experiment. In the 'dwell' period, before heater activation, some small pressures were generated initially, giving a non-uniform pressure distribution at day zero. It was thought that stresses were induced during compaction of the buffer into the borehole, and as expected the pressures are greater at the base of the borehole, as the buffer was compacted in a series of layers into the borehole. A good degree of axial symmetry was noted in these readings.

Once the heater was activated, the horizontal and vertical pressures increased within the experiment. The vertical pressure cells immediately above and below the heater demonstrated a large initial increase in pressure. This pressure then dissipated, before again increasing later in the experiment. This initial increase has been attributed by
Kjartanson et al. (1993) to the impact of thermal expansion of both the heater and the nearby buffer. The swelling pressures in the experiment were larger at the base of the experiment. The buffer in this region had more potential to absorb moisture from the rock owing to the proximity to both the base of the experiment and the side of the borehole. Pressures measured in the backfill were low.

\section{Displacements in rock and restraining cap}

Borehole extensometers were used to measure the vertical displacements in the rock adjacent to the emplacement borehole. It was noted that during the heating phase the displacements were very small, with a maximum of only $0.72 \mathrm{~mm}$ occurring at the mid-height of the heater. There was a strong correlation between the strain and the temperature measurements in the rock, with the cooler areas above and below the heater deforming to a lesser degree. The overall influence of displacements in the rock on the deformation of the buffer was negligible.

A rigidly restrained top cap was used in the $\mathrm{BCE}$ to inhibit swelling of the buffer and minimise moisture loss or gain between the top of the backfill and Room 213, and peak pressures of $350 \mathrm{kPa}$ were measured within the restraint system during the course of the experiment.

\section{THEORETICAL AND NUMERICAL MODEL}

In order to examine the experimentally observed behaviour, a series of numerical analyses have been performed. In particular, a coupled thermo-hydraulic-mechanical theoretical formulation solved by a coupled finite element/finite difference algorithm has been utilised. Full details of the theoretical formulation and the numerical solution have been presented in detail elsewhere (Thomas \& He, 1997, 1998; Thomas et al., 2003). In particular, the elasto-plastic constitutive presented by Alonso et al. (1990) has been used.

As mentioned above, part of this study is the investigation of the influence of previously identified (Thomas et al., 2003) swelling and micro-macro interactions on the behaviour of a non-isothermal system, and therefore details of the approach used are given here. Micro-macro interactions are considered by way of a simple model proposed by Thomas et al. (2003), which considers the impact of swelling and micro-macro interactions on the hydraulic conductivity of the material. This approach was based on a study of the isothermal test, carried out in conjunction with the $\mathrm{BCE}$, which indicated that the micro- and macrostructure of a bentonite buffer material may have a pronounced effect on the resaturation rates of the material. It was proposed that, as water enters the buffer, the majority of it becomes adsorbed within the microstructure, and hence is unavailable for further flow. Furthermore, expansion of the microstructure within a highly confined system reduces the volume of the macropores, thereby reducing the effective hydraulic conductivity of the material. This led to the proposal of a relationship that, as a first approximation, linked the hydraulic conductivity with both the degree of saturation and the proportion of soil water that is adsorbed: details of this relationship are given below in the next section.

\section{MATERIAL PARAMETERS}

The modelled domain consists of five different materials - a sand/bentonite buffer, the host granite rock, a backfill, and a sand-and each of these requires the definition of a full set of thermo-hydraulic-mechanical material parameters. Hydro-mechanical material parameters for the granite (Thomas et al., 2003), the sand/bentonite buffer (Thomas et 


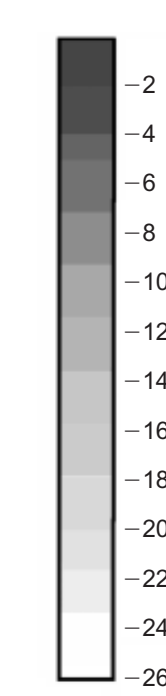

Pore water pressure: $\mathrm{kPa}$

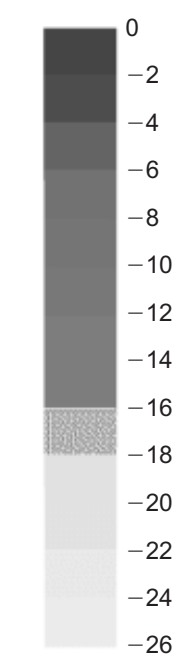

Pore water pressure: $\mathrm{kPa}$
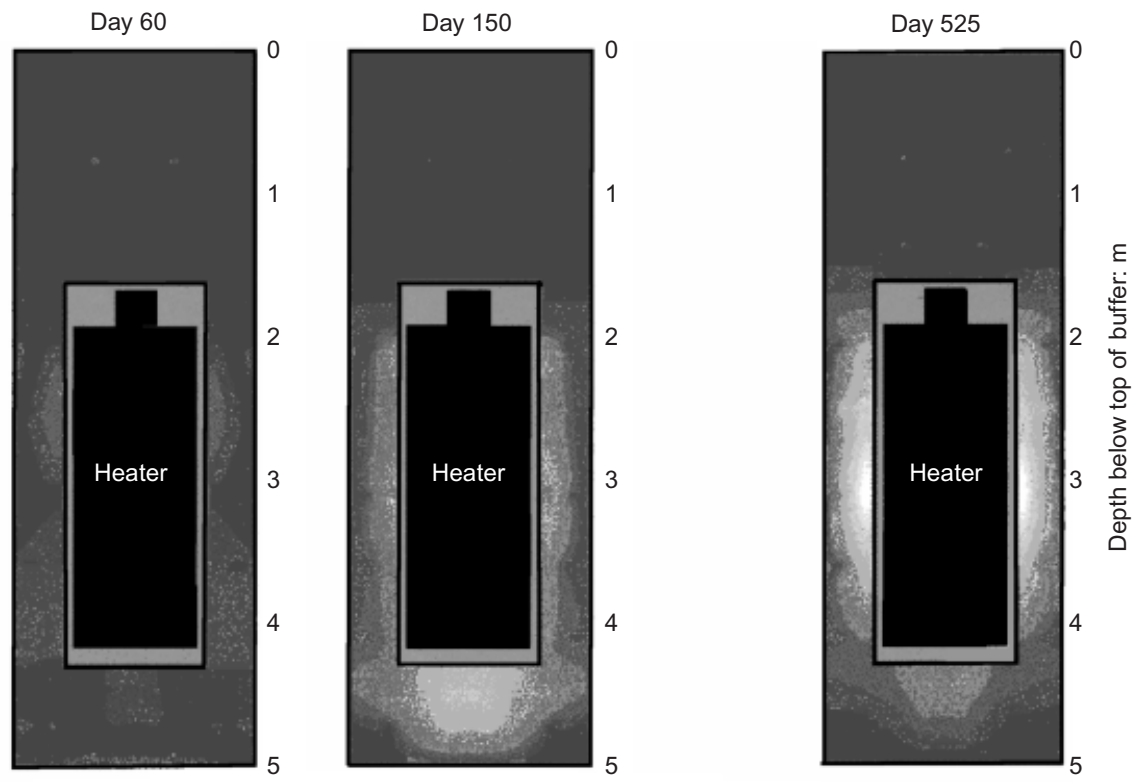

Experimental results (after Graham et al., 1997)
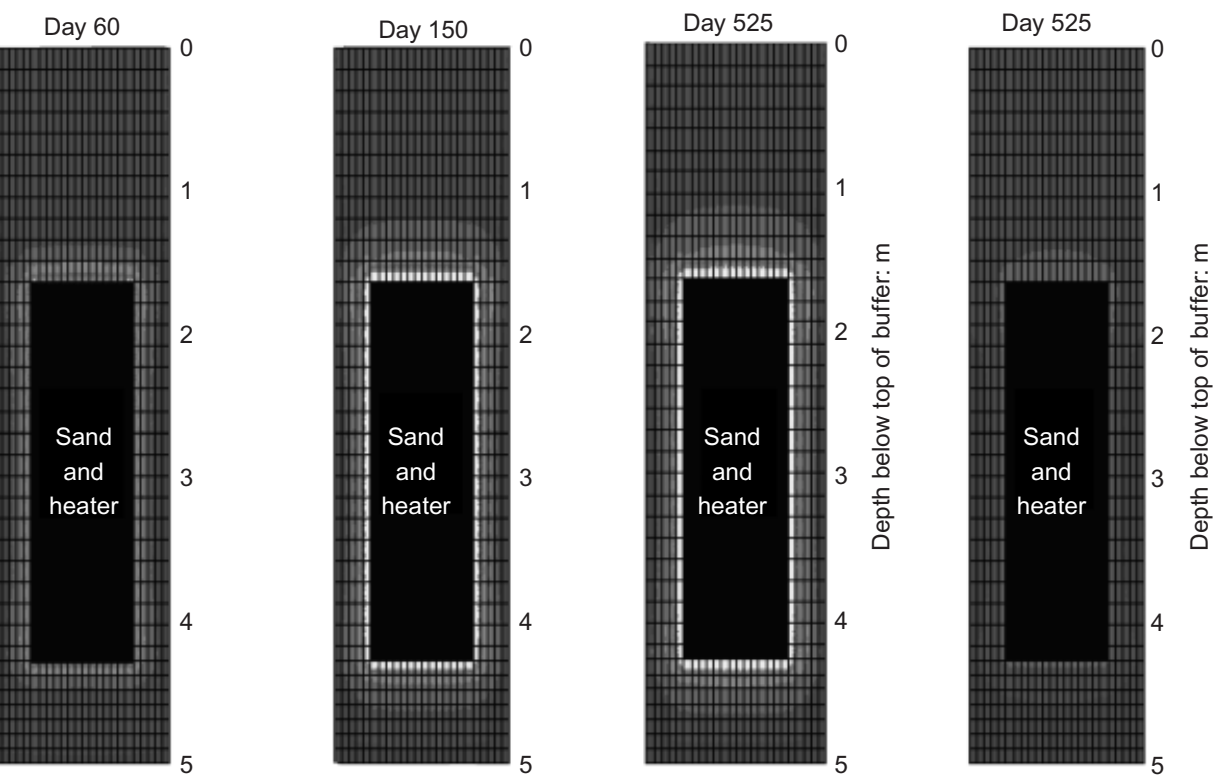

Numerical simulation

Numerical (Green \& Corey)

Fig. 9. Transient change of pore water pressure contours

al., 2003) and the sand (Thomas \& Li, 1997), have been presented previously, and therefore they are only briefly discussed here, along with some additional parameters. Finally, the material parameters implemented for the backfill are discussed.

\section{Bentonite/sand buffer material parameters}

In the BCE the buffer had an initial dry density of $1.76 \mathrm{Mg} / \mathrm{m}^{3}$ and an initial gravimetric water content of $18 \%$ (Graham et al., 1997). This corresponds to an initial degree of saturation of $91 \%$ and an initial porosity of 0.348 for the material. Following the approach described in Thomas et al. (2003), data from Wan et al. (1995a) were used to yield the moisture content relationship, as follows

$$
S_{1}=1+1.69 \times 10^{-11}\left[1-\exp \left(8.246 \times 10^{-6} \times s\right)\right]
$$

when $s<2.58 \mathrm{MPa}$

$$
S_{1}=-0.534 \log _{10}(s)+4.395
$$

when $2.58 \mathrm{MPa} \leqslant s \leqslant 17 \mathrm{MPa}$

$$
S_{1}=-0.355 \log _{10}(s)+3 \cdot 106 \text { when } 17 \mathrm{MPa}<s
$$

where $s$ is the total suction and $S_{1}$ is the degree of saturation. Again following Thomas et al. (2003), two approaches to describe the unsaturated hydraulic relationship are utilised. The first is based on the micro-macro approach proposed by Thomas et al. (2003), who presented the relationship

$$
k=k_{1} \frac{e}{e_{\mathrm{i}}}\left[S_{\mathrm{a}}+0 \cdot 06 S_{1}\left\{\exp \left[-100(1-0.06) S_{1}\right]\right\}\right]
$$

where $k$ is the modified unsaturated hydraulic conductivity, $k_{1}$ is the unsaturated hydraulic conductivity, $S_{\mathrm{a}}$ is the degree of saturation of pore air, $e$ is the void ratio and $e_{\mathrm{i}}$ is the initial void ratio of the clay. This relationship is presented graphically in Fig. 12, for a constant void ratio. In this approach it is postulated that, as the buffer absorbs moisture, 
$\left.\right|_{-2} ^{8}-2$

Increase in moisture content

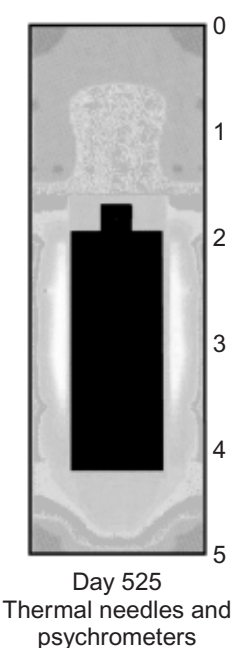

psychrometers

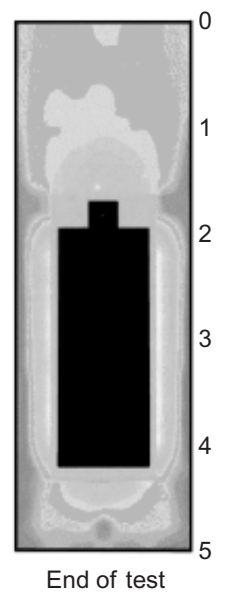

Calculated from

decommissioning water contents
Fig. 10. Comparison of distributions of water contents from thermal needles and psychrometers, and from decommissioning water contents (after Graham et al., 1997)

swelling of the microstructure of the material reduces the flow of moisture in the macrostructure.

A second relationship, based on the method proposed by Green \& Corey (1971), is also presented to allow comparison between the micro-macro model and a more 'standard' approach. Both approaches use a measured saturated hydraulic conductivity of $5 \times 10^{-12} \mathrm{~m} / \mathrm{s}$ (Graham et al., 1997). The form of the variation with degree of saturation is shown in Fig. 12.

A relationship describing the thermal conductivity of the buffer is based on experimental measurements presented by Wan et al. (1995b), and is defined by

$$
\begin{aligned}
\lambda & =0.7 \mathrm{~W} / \mathrm{m} \mathrm{K} ; \quad S_{1}<0.164 \\
\lambda & =2.17 S_{1}+0.345 \mathrm{~W} / \mathrm{m} \mathrm{K} ; 0.164 \leqslant S_{1} \leqslant 0.763 \\
\lambda & =2.0 \mathrm{~W} / \mathrm{m} / \mathrm{K} ; 0.763<S_{1}
\end{aligned}
$$

where $\lambda$ is the thermal conductivity. The value of specific heat capacity, $1254.8 \mathrm{~J} / \mathrm{kg} \mathrm{K}$, was derived from data presented by Radhakrishna et al. (1990). The mechanical material parameters are as presented by Thomas et al. (2003).

\section{Granite material parameters}

The hydraulic and mechanical material parameters utilised for the granite are as described by Thomas et al. (2003). The thermal conductivity for the granite was taken as a constant value of $3.6 \mathrm{~W} / \mathrm{m} \mathrm{K}$ after Graham et al. (1997). The specific heat capacity for the rock was given in Graham et al. (1997) as $1060 \mathrm{~J} / \mathrm{kg} \mathrm{K}$.

\section{Sand material parameters}

A comparison of the particle size distribution for the sand used in the BCE and a previously well-defined Garside Grade medium sand (Ewen \& Thomas, 1989; Thomas \& Li, 1997) showed the materials to be very similar. Therefore material parameters previously presented by Thomas \& $\mathrm{Li}$ (1997) for this Garside Grade medium sand were employed. It was assumed that the sand was an undeformable rigid material, and therefore no mechanical material parameters were required.

\section{Backfill material parameters}

Little information relating to the material parameters of the backfill material is available. Therefore, where not directly available for the backfill, material parameters used for the sand/bentonite buffer were adopted. The similarity between the buffer (a 50:50 sand-clay mixture) and the backfill (a $75: 25$ sand-clay mixture) should be noted.

In the BCE the backfill had an initial dry density of $2 \cdot 13 \mathrm{Mg} / \mathrm{m}^{3}$, an initial gravimetric water content of $7 \cdot 2 \%$, and an initial porosity of 0.233 (Graham et al., 1997). The moisture retention curve has been determined based on experimental data presented by Wan et al. (1995b), following the same methodology as that presented above for the buffer material, as

$$
\begin{aligned}
S_{1}= & 1+1.5 \times 10^{-32}\left[1-\exp \left(4.1464 \times 10^{-6} \times s\right)\right] ; \\
& \mathrm{s}<16.65 \mathrm{MPa} \\
S_{1}= & -0.974 \log _{10}(s)+8.015 ; 16.65 \mathrm{MPa} \leqslant s \leqslant 17 \mathrm{MPa}
\end{aligned}
$$

$$
S_{1}=-0.648 \log _{10}(s)+5 \cdot 664 ; 17 \mathrm{MPa}<s
$$

The unsaturated hydraulic conductivity curve was again determined using the approach proposed by Green \& Corey (1971), using a measured saturated hydraulic conductivity of $10^{-10} \mathrm{~m} / \mathrm{s}$ (Graham et al., 1997). As both the sand content and the saturated hydraulic conductivity are considerably higher than in the buffer material it was considered most reasonable to use the more standard approach for the description of the unsaturated hydraulic conductivity, as the approach presented by Thomas et al. (2003) had only be empirically obtained for the buffer material. The variation of the unsaturated hydraulic conductivity with degree of saturation is shown in Fig. 12. As no alternative data were available, mechanical material parameters used for the buffer have been adopted in the analysis of the backfill.

While the uncertainty related to the material parameters for the backfill material is recognised, this region of material is relatively isolated, both thermally and hydraulically, from the rest of the domain. In particular, the experimental data indicate low thermal gradients and limited moisture infiltration in this region. The impact of this uncertainty on the backfill material parameters was checked in a series of sensitivity analyses, and found to be of little significance.

\section{NUMERICAL SIMULATIONS}

A series of numerical simulations of the system have been undertaken. These simulations can be divided into two groups: those related to the pre-heating phases $(\mathrm{A}-\mathrm{C})$ of the experiments, and those related to the heating phase (D). Essentially, the first group of simulations are performed to establish the initial conditions of the experimental phase D.

A two-dimensional axisymmetric geometry has been used, owing to the axisymmetrical nature of the experimental geometry and the experimentally measured data, and to the transverse isotropy of the thermal properties of the materials. Several numerical investigations related to the domain size, the far-field boundary conditions, the mesh discretisation and the time-stepping discretisation have been performed to ensure that converged solutions have been obtained, and that the representation of experimentally ill-defined far-field boundary conditions did not adversely affect the analyses. Two finite element meshes were used: one $15 \mathrm{~m}$ radius by $30 \mathrm{~m}$ high (Fig. 13), and one $15 \mathrm{~m}$ radius by $16 \mathrm{~m}$ high (Fig. 14). In both cases eight-noded isoparametric quadrilateral elements were employed. Temporal convergence was obtained using an initial time step of $60 \mathrm{~s}$, which was allowed 


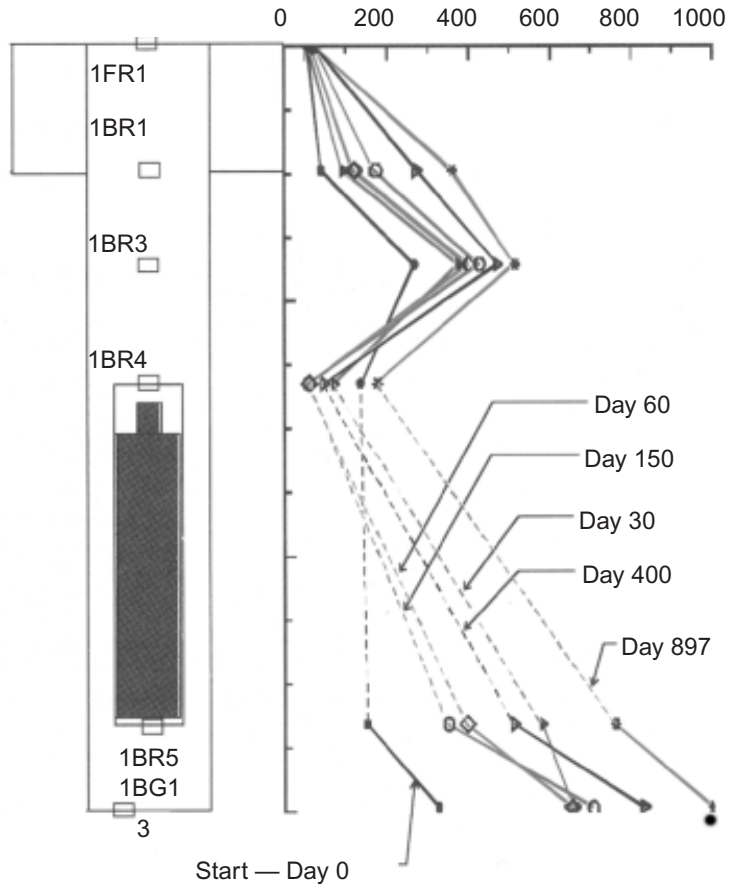

(a)

Pressure: $\mathrm{kPa}$ Pressure: $\mathrm{kPa}$

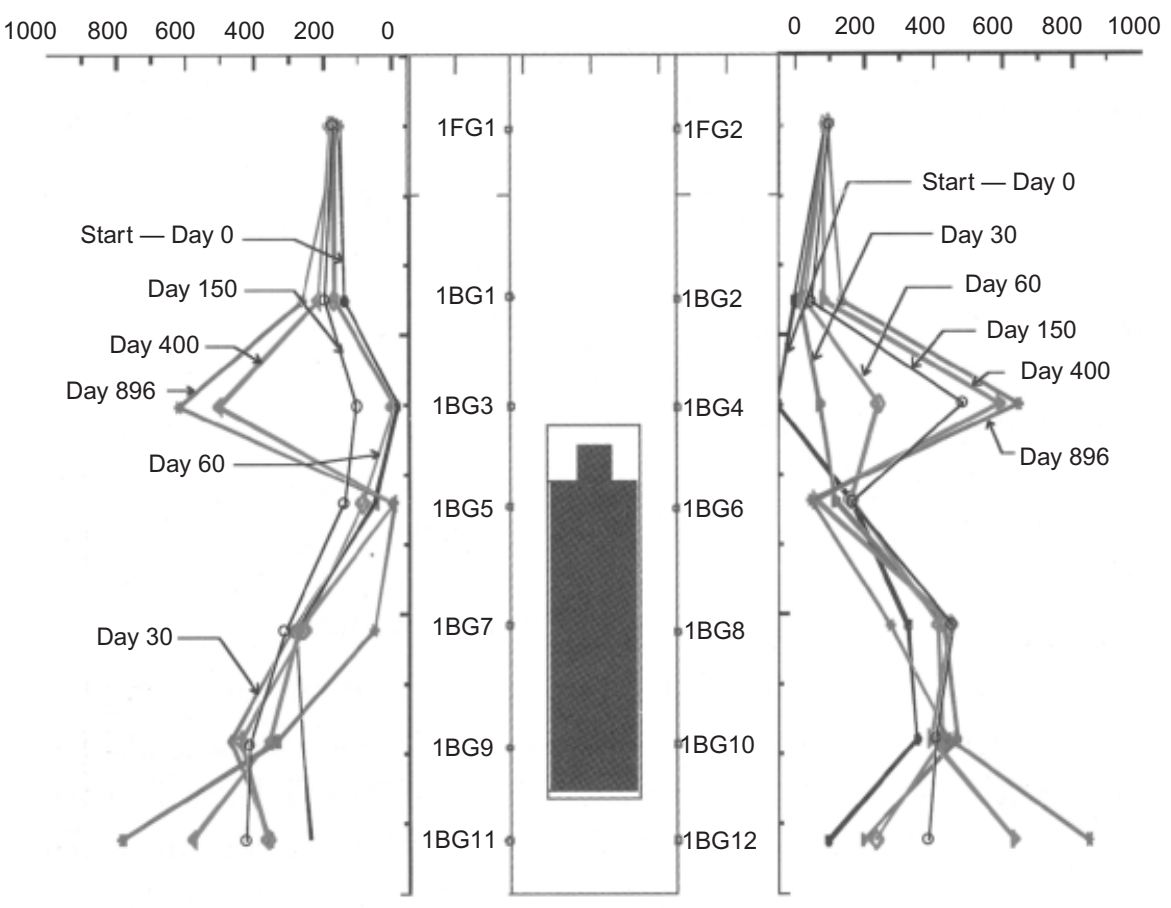

(b)

Fig. 11. Transient total pressures in buffer and backfill (after Graham et al., 1997): (a) vertical pressure; (b) horizontal pressure

gradually to increase to 30 days, depending on certain convergence criteria being met.

SIMULATION OF THE PRE HEATING PHASES (A-C)

Phase A of the experiment consisted of drilling and monitoring the emplacement borehole. The construction of the underground repository and drilling of the emplacement borehole meant that there was an initial drawdown of the pore water pressure in the rock. The hydraulic behaviour of this phase was modelled using the $15 \mathrm{~m} \times 30 \mathrm{~m}$ mesh shown in Fig. 13. As the relative humidity in the cavern was maintained at nearly $100 \%$, and the air was at atmospheric pressure during the placement period of the experiment, the cavern and the borehole boundaries were fixed at zero pore water pressure. On the far-field boundaries pore water pressure was fixed at values varying with depth between $1450 \mathrm{kPa}$ and $1750 \mathrm{kPa}$, to give an average far-field pressure 


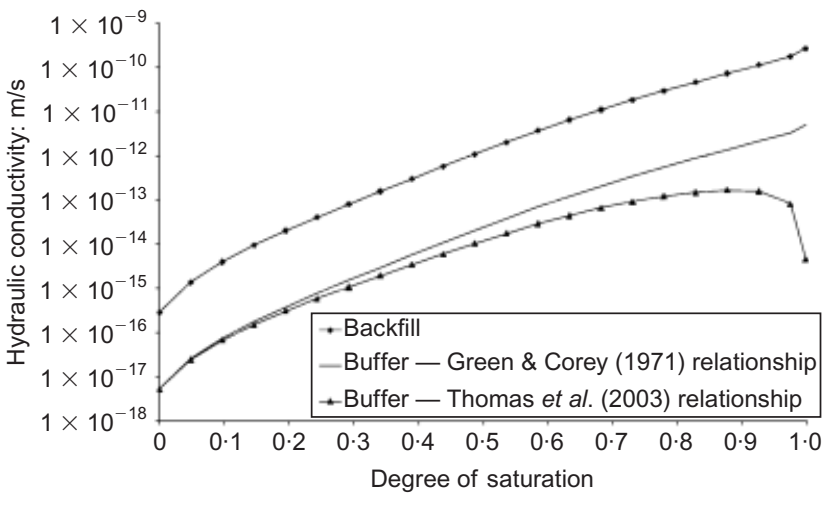

Fig. 12. Hydraulic conductivity for sand/bentonite buffer and backfill

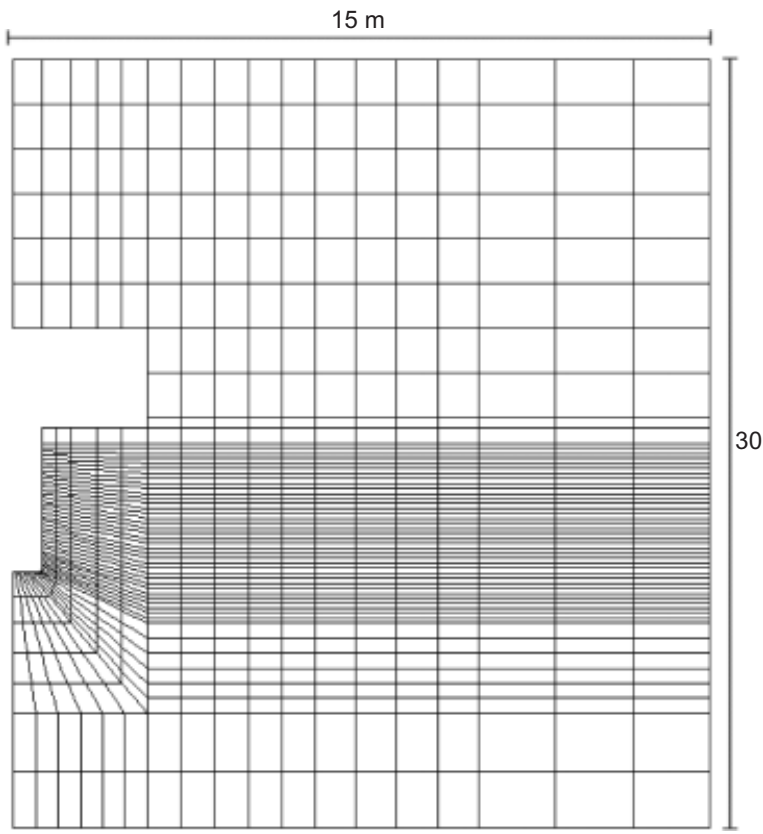

Fig. 13. $15 \mathrm{~m} \times 30 \mathrm{~m}$ finite element mesh

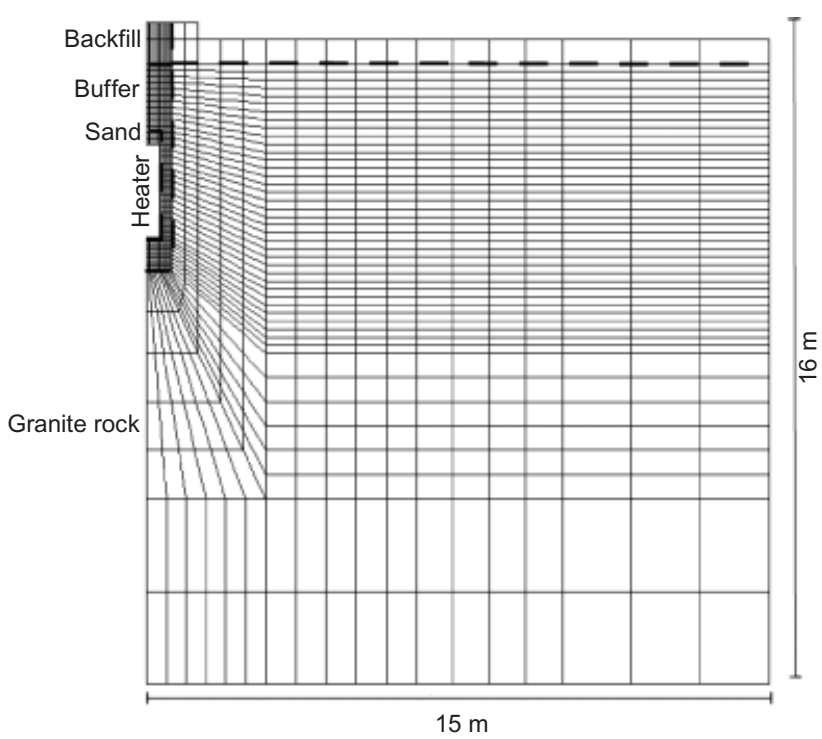

1165 eight-noded quadrilateral elements

Fig. 14. $15 \mathrm{~m} \times 16 \mathrm{~m}$ finite element mesh of $1600 \mathrm{kPa}$ (Chandler et al., 1992). Initial pore water pressures in the rock followed a similar variation with depth. Similarly, the top and bottom boundaries were fixed at $1450 \mathrm{kPa}$ and $1750 \mathrm{kPa}$ respectively. The remaining boundaries, which coincide with the axisymmetrical axis of symmetry of the system, were by default given a zero flow boundary condition.

The problem was simulated for 280 days, at which point the pore water pressures had reached steady state. No comparison with the experimental data was made at this stage, as the hydraulic packers were unstable during the drilling process. The steady-state pore water pressures obtained from this simulation were used as the initial conditions for the simulation of phases $\mathrm{B}$ and $\mathrm{C}$ of the experiment.

Phases $\mathrm{B}$ and $\mathrm{C}$ of the experiment consisted of the installation of the buffer and backfill, and a 'dwell' period that was intended to allow temperatures, total pressures and pore water pressures to stabilise. For this set of numerical simulations the mesh shown in Fig. 14 was utilised, with a thermo-hydraulic analysis being undertaken. Once the initial drawdown of pore water pressure in the rock had been accounted for, the influence of the upper boundary of the mesh shown in Fig. 13 was negligible, and a mesh of reduced size could be utilised, thereby substantially increasing the speed of the numerical analysis. The buffer was placed at $17.9 \%$ gravimetric moisture content, and according to the water retention curve defined above this relates to an initial suction of $3.98 \mathrm{MPa}$. The initial temperatures were taken from experimental values (Graham et al., 1997). The analysis was run for 200 days.

Simulated pore water pressure distributions in the rock at the end of the dwell period are shown in Fig. 6: they closely match the experimental results measured in the majority of the hydraulic packers. The two points for which a poor comparison can be seen were read from packers that were considered unstable (Graham et al., 1997). Comparison of the extent of rock desaturation at the mid-height of the heater showed a simulated desaturation distance of approximately $1.9 \mathrm{~m}$ from the centre of a heater, which gives a good match to the experimental desaturation distance of approximately $2 \mathrm{~m}$ observed in the piezometers. Considering moisture movement into the buffer, comparison of the simulated average suction in the buffer of $3.34 \mathrm{MPa}$ gives a good correlation with the experimentally measured average value of $3.3 \mathrm{MPa}$.

Simulation of phases A-C has allowed assessment of the ability of the model to describe the hydraulic regime in the host rock and isothermal infiltration into the buffer. In both cases it has been found that the model is able to capture the experimentally observed behaviour, with both the extent of desaturation of the rock close to the borehole and the quantity of resaturation of the buffer well matched. Furthermore, the close correlation gives confidence in using the calculated results to establish the initial conditions for analysis of the heating phase of the experiment.

\section{SIMULATION OF THE HEATING PHASE (D)}

Following the 'dwell' period, the heater was activated for 896 days. This heating phase has been simulated with a thermo-hydraulic-mechanical analysis, adopting the mesh shown in Fig. 14. Pore water pressures and temperatures calculated at the end of the 'dwell' period were taken as the initial conditions. On the lower and vertical far-field boundaries the initial temperatures and pore water pressures were fixed at their initial conditions. A constant temperature of $288 \mathrm{~K}$ was adopted at the cavern floor boundary, with a zero flux boundary condition applied for the temperature field along the remainder of this upper boundary. Results of 
analyses applying this condition were compared with results for analyses where a fixed temperature was applied along the whole of this upper boundary, and the difference between the two sets of numerical results was less than $0.5 \%$. A time-dependent heat flux was applied at the heater boundaries to represent the thermal loading from the canister, where the power to the heater was held constant at $1000 \mathrm{~W}$ for the first 25 days of heating, and was then increased to $1200 \mathrm{~W}$ for the remainder of the heating period.

After some numerical investigation it was found that the assumption that no deformations occurred in the rock had negligible influence on the stress development in the buffer, and considerably reduced the computational time required: therefore this approach was followed here. The top of the backfill was also prevented from deforming in the vertical direction, representing the presence of the concrete cap and restraints. An average initial uniform stress of $200 \mathrm{kPa}$ was assumed throughout the buffer, based on the experimental values shown in Fig. 11. It was also assumed that the sand was densely compacted within the sand annulus, and therefore would not compress as the buffer swelled.

The simulation presented utilises the hydraulic conductivity relationship based on the proposals of Thomas et al. (2003), and the results from this simulation are labelled as 'numerical simulation' data in Figs 4-9. Results from a second simulation using the Green \& Corey hydraulic conductivity relationship are also presented, and are labelled as 'Numerical (Green \& Corey)' data. This second simulation allows a comparison between the two approaches to be made, and the influence of the micro-macro interactions identified by Thomas et al. (2003) to be assessed using an independent and more complex non-isothermal experiment.

\section{Thermal field}

The transient temperature results for the heating period are given in Figs 4 and 5. Fig. 4 shows the transient temperature profiles for a cross-section at the mid-height of the heater. The numerical results correlate well with the experimental values. They demonstrate a change in the temperature gradient from the sand layer to the buffer layer, and from the buffer layer to the rock layer. The results indicate that the temperature field is well represented in the system. Fig. 5 shows the transient temperature profiles along the axis of the emplacement borehole. The numerically modelled temperatures in the buffer demonstrated a good correlation with the experimental values. The experiment temperatures quoted were measured on the skin of the heater, and so the temperature within the sand annulus at the heater/sand interface would be expected to be slightly lower.

\section{Moisture field}

Figure 7 shows the numerical and experimental transient contour plots of pore water pressure for the near-field granite rock following activation of the heater. The numerical results indicate an increase, with time, of the pore water pressure in the rock in this region throughout the heating phase, as the pore water pressure levels recharged, following the initial drawdown due to the room construction. As discussed earlier, the experimental contours were strongly influenced by two of the hydraulic packers that read unusually high pore water pressures: if their influence were removed from the contour plots the overall pattern would be reflected more closely by the simulated trend of pore water pressure increase, although the increases would still be underpredicted.

Figure 8 shows pore water pressure profiles for three different depths below the top of the buffer. The hydraulic
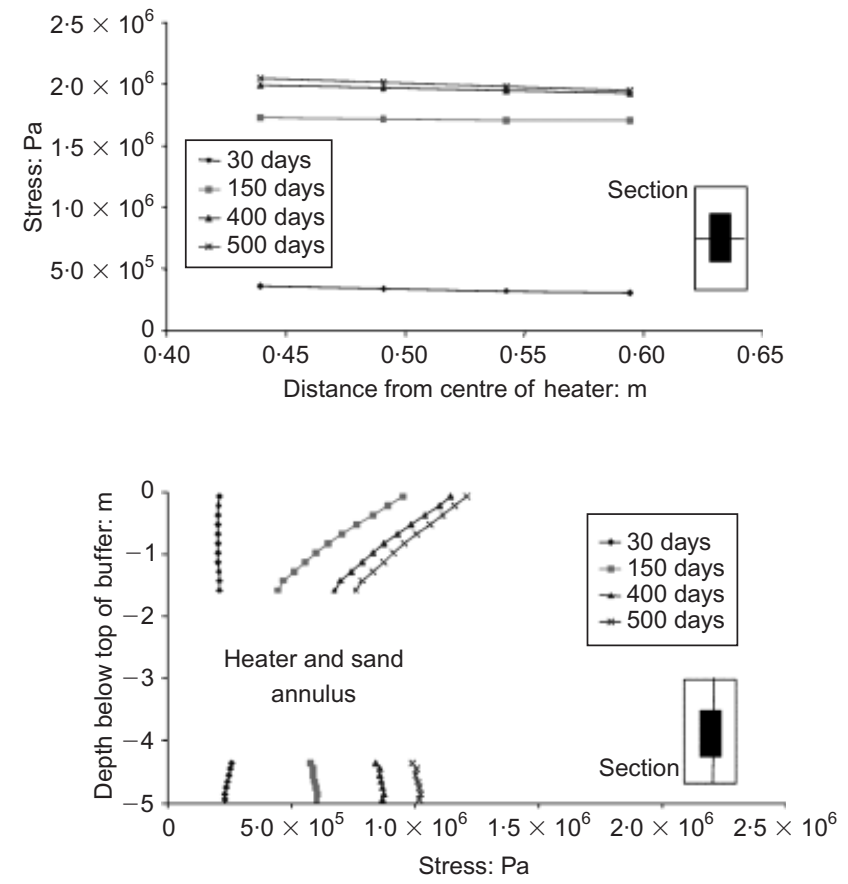

Fig. 15. Numerical swelling pressure in buffer, at mid-height of heater, and for vertical section at radius of $0.03 \mathrm{~m}$ from centre of heater

piezometers cavitated as the pore water pressures approached $-100 \mathrm{kPa}$, and therefore lower pore water pressures could not be recorded. At a level of $-3 \mathrm{~m}$ below the top of the buffer the instrumentation consisted wholly of piezometers. A reasonable correlation with the experimental pore water pressures was achieved in this region after 30 days. When comparing against the experimental results measured by the hydraulic piezometers it can be seen that the pore water pressures calculated at 150 days and 400 days are higher. This may in part be due to the hydraulic piezometers IRP2M to IRP5M being located in the region of relatively higher hydraulic conductivity leucocratic granite discussed above. As this variation in permeability of the granite material is not incorporated in the analysis, higher calculated pressures might be expected. At depths of $-1.4 \mathrm{~m}$ and $-3.5 \mathrm{~m}$ below the top of the buffer the instrumentation consisted mainly of hydraulic packers, and in these regions a good correlation between the numerical simulation and the experimental results is found.

The simulation results can be compared with those obtained using the more standard Green \& Corey approach for transient pore water pressure profiles in the rock at various heights in Fig. 8. By day 150 simulated pore water pressures were increasing at a greater rate than for the Green \& Corey analysis. This produced a closer correlation with the experimental results measured using the hydraulic packers. As described earlier, it is postulated that, as the buffer absorbed moisture, swelling of the microstructure of the buffer reduced the flow of moisture from the rock to the buffer, and the pore water pressures in the rock subsequently increased. This reflects the pattern of behaviour observed previously in AECL's isothermal test.

The numerical pore water pressure contours simulated for the buffer are shown in Fig. 9, and are compared with the experimental pore water pressure contours interpreted from the thermal needle and psychrometer outputs. In Fig. 9 the simulation overpredicts drying above and below the heater after 525 days. However, the numerical calculated results compare more favourably with the end-of-test moisture content results shown in Fig. 10. In the experiment, almost 
equal amounts of drying occur above and below the heater, with the quantity of drying above and below the heater being slightly less than that at the side of the heater. The buffer is approaching saturation in the region adjacent to the heater and at the base of the borehole, for both the end-oftest and the numerically modelled results. The results provide a closer correlation with the experimental results than for the analysis using the Green \& Corey approach. This provides a further indication of the ability of the theoretical approach proposed previously (Thomas et al., 2003) to represent the micro-macro behaviour of the soil, even with the additional influence of thermal gradients.

\section{Stress-strain field}

Simulated swelling pressures developed in the buffer for both a vertical and horizontal section are shown in Fig. 15. The calculated stress is fairly uniform in the horizontal direction, and increases throughout the course of the experiment. Swelling pressures are developed as the buffer absorbs moisture from the rock, and moisture migrates from the heated region. The experimental total pressures are shown in Fig. 11. The numerical horizontal stresses at the mid-height of the heater qualitatively match the increase in pressure shown in the experimental results. However, quantitatively the numerical values are considerably larger than the experimental values. Comparison along the vertical profiles shows both a reasonable quantitative and a qualitative match between the experimental and the numerical results, particularly below the heater.

Simulation of the heating phase of the experiment allows both assessment of the numerical model and consideration of the influence of the microstructure of the buffer material. It is clear that the temperature field is well understood, with a good correlation between the numerical and experimental results. It can be concluded that the thermal behaviour is well represented in the numerical model. Consideration of the moisture field shows that the interaction between the emplaced buffer and host rock is of significant importance. In particular, analyses where a conventional hydraulic conductivity relationship is used for the buffer material yield overestimated levels of resaturation in the buffer and underestimated pore water pressures in the rock. A significantly better correlation was achieved both in the buffer and the rock when the micro-macro behaviour of the buffer was considered. In terms of the stress-strain analysis a reasonable comparison is found between the calculated and observed response of the system.

\section{CONCLUSIONS}

This paper has considered the thermo-hydraulic-mechanical behaviour of a large in situ heating test carried out at Atomic Energy of Canada's (AECL) underground research laboratory, the Buffer/Container Experiment (BCE).

In terms of the experimental results, the thermal field followed expected patterns, with the influence of variations of thermal conductivity due to changes in material type revealed. The hydraulic response of the system was seen to be more complex, with both the interaction between the regions of saturated host granite and the emplaced buffer and the effect of the heater influencing behaviour. In the buffer, water uptake is observed close to the rock/buffer interface, and significant drying was measured close to the heater.

As part of the numerical investigation the micro-macro behaviour of bentonitic buffer materials subjected to resaturation in confined non-isothermal conditions has been included. In particular, the approach presented in Thomas et al. (2003) for isothermal conditions has been employed.

Comparisons of numerical simulations of each stage of the experiment have been presented. The simulation of phases A-C has both: (a) demonstrated the ability of the model to describe the hydraulic regime in the host rock and isothermal infiltration into the buffer, with both the extent of desaturation of the rock close to the borehole and the quantity of resaturation of the buffer well matched; and (b) established the initial conditions for the analysis of the heating phase of the experiment.

Simulation of the heating phase of the experiment has confirmed that the temperature field is well understood, with a good correlation between the numerical and experimental results.

Consideration of the moisture field shows that the interaction between the emplaced buffer and host rock is of considerable importance. It was found that inclusion of micro-macro interaction effects, by way of consideration of the impact of swelling and micro-macro interactions on the hydraulic conductivity of the material, yielded significantly improved correlations between observed and calculated results in the moisture field. While it is recognised that the particular approach taken in this study is relatively simple, this general conclusion may be of some significance in considering the total resaturation time as part of the performance assessment of a nuclear waste disposal repository.

\author{
NOTATION \\ $e$ void ratio \\ $e_{\mathrm{i}}$ initial void ratio \\ $k$ modified unsaturated hydraulic conductivity \\ $k_{1} \quad$ unsaturated hydraulic conductivity \\ $S_{\mathrm{r}}$ degree of saturation of pore liquid \\ $s$ total suction \\ $\lambda$ thermal conductivity
}

\section{REFERENCES}

AECL (1994). Environmental impact statement on the concept for disposal of Canada's nuclear fuel waste, AECL-10711, COG93-1. Ontario: Atomic Energy of Canada Limited.

Alonso, E. E., Gens, A. \& Josa, A. (1990). A constitutive model for partially saturated soils. Géotechnique 40, No. 3, 405-430.

Andersson, C., Bárcena, I., Bono, N., Boergesson, L., Cleall, P., Forsmark, T., Gunnarsson, D., Johannesson, L.-E., Ledesma, A., Liedtke, L., Luukkonen, A., Pedersen, K., Puigdomenech, I., Pusch, R., Rhén, I., Rothfuchs, T., Sandén, T., Sineriz, J.-L., Sugita, Y., Svemar, C. \& Thomas, H. (2005). Full-scale testing of the KBS-3V concept for the geological disposal of high-level radioactive waste (prototype repository): Final report, Contract No FIKW-CT-2000-00055. European Atomic Energy Community's R\&T Specific Programme 'Nuclear Energy, Key Action: Nuclear Fission Safety 1998-2002' Area: Safety of the Fuel Cycle Directorate-General for Research Euratom EUR 21924.

Chandler, N. A. (2000). Water inflow calculations for the isothermal buffer-rock-concrete plug interaction test', Used Fuel Disposal Technology Program Report 06819-REP-01200-10046-R00. Ontario Power Generation.

Chandler, N. A., Kjartanson, B. H., Kozak, E. T., Martin, C. D. \& Thompson, P. M. (1992). Monitoring the geomechanical and hydrogeological response in granite for AECL research's buffer/ container experiment. Proc. 33rd US Symp. on Rock Mechanics, Sante Fe, 161-170.

Cleall, P. J., Melhuish, T. A. \& Thomas, H. R. (2006). Modelling the three-dimensional behaviour of a prototype nuclear waste repository. Engng Geol. 85, No. 2, 212-220.

Dixon, D. A., Thompson, P. M., Chandler, N. A. \& Kozak, E. T. (2000). Instrumentation summary report for the isothermal and buffer/container experiments, Used Fuel Disposal Technology 
Program Report 06819-REP-01200-10035-R00. Ontario Power Generation.

Dixon, D. A., Chandler, N., Graham, J. \& Gray, M. N. (2002). Two large-scale sealing tests conducted at Atomic Energy of Canada's underground research laboratory: the buffer-container experiment and the isothermal test. Can. Geotech. J. 39, No. 3, $503-518$

European Commission (2007). Work Programme 2008: EURATOM for Nuclear Research and Training Activities., C(2007) 5750. Brussels: European Commission.

Ewen, J. \& Thomas, H. R. (1989). Heating unsaturated medium sand. Géotechnique 39, No. 3, 455-470.

Graham, J., Chandler, N. A., Dixon, P. J., Roach, To T. \& Wan, A. W. L. (1997) The Buffer/Container experiment: results, synthesis, issues, Technical Report AECL-11746, COG-97-46-I. Ontario: Atomic Energy of Canada Limited.

Green, R. E. \& Corey, J. C. (1971). Calculation of hydraulic conductivity: a further evaluation of some predictive methods. Proc. Soil Soc. Am. 35, 3-8.

Huertas, F., de la Cruz, B., Fuentes-Cantillana, J. L., Alonso, E., Linares, J., Samper, J., Elorza, F. J., Svemar, C., Salo, J.-P., Muurinen, A., Pacovský, J., Verstricht, J., Bazargan-Sabet, B., Jockwer, N., Vignal, B., Shao, H., Kickmaier, W., Baeyens, B., Börgesson, L., Rhén, I., Villieras, F., Robinet, J. C. \& Gourry, J. C. (2005). Full-scale engineered barriers experiment for a deep geological repository for high-level waste in crystalline host rock-Phase II FEBEX II Final report, Contract No FIKWCT-2000-00016, European Atomic Energy Community's R\&T Specific Programme 'Nuclear Energy, Key Action: Nuclear Fission Safety 1998-2002' Area: Safety of the Fuel Cycle Directorate-General for Research Euratom EUR 21922

Kjartanson, B. H., Chandler, N. A., Wan, A. W. L., Radhakrishna, H. S. \& Lau, K. C. (1993). In situ assessment of bentonite/sand buffer material. Proceedings of the 1993 Joint CSCE-ASCE
National Conference on Environmental Engineering, Montreal, 747-755.

Radhakrishna, H. S., Lau, K.-C., Kjartanson, B. H. \& Cheung, S. C. H. (1990). Modelling the in situ performance of bentonitesand buffer. Mater. Res. Soc. Symp. Proc. 176, 725-732.

SKB (2007). RD\&D programme 2007: Programme for research, development and demonstration of methods for the management and disposal of nuclear waste, SKB Technical Report 07-12. Stockholm: SKB.

Thomas, H. R. \& He, Y. (1997). A coupled heat-moisture transfer theory for deformable unsaturated soil and its algorithmic implementation. Int. J. Numer. Methods Engng 40, No. 18, $3421-3441$.

Thomas, H. R. \& He, Y. (1998). Modelling the behaviour of unsaturated soil using an elasto plastic constitutive relationship. Géotechnique 48, No. 5, 589-603.

Thomas, H. R. \& Li, C. L. W. (1997). An assessment of a model of heat and moisture transfer in unsaturated soil. Géotechnique 47, No. 1, 113-131.

Thomas, H. R., Cleall, P. J., Chandler, N., Dixon, D. \& Mitchell, H. P. (2003). Water infiltration into a large-scale in situ experiment in an underground research laboratory. Géotechnique 53, No. 2, 207-224.

Villar, M. V., Garcia-Sineriz, J. L., Barcena, I. \& Lloret, A. (2005). State of the bentonite barrier after five years operation of an in situ test simulating a high level radioactive waste repository. Engng Geol. 80, Nos 3-4, 175-198.

Wan, A. W. L., Gray, M. N. \& Chandler, N. (1995a), Tracking in situ moisture transients in heated clay. Proc. 1st Int. Conf. on Unsaturated Soils, Paris, 925-932.

Wan, A. W. L., Gray, M. N. \& Graham, J. (1995b). On the relations of suction, moisture content, and soil structure in compacted clays. Proc. 1st Int. Conf. on Unsaturated Soils, Paris, 215-222. 